\title{
Thyroid diseases in a school population with thyromegaly
}

\author{
Jasminka Jakšić, Miro Dumić, Boris Filipović, Jasenka Ille, Maja Cvijetić, Gorjana Gjurić
}

\begin{abstract}
A survey of 5462 schoolchildren was conducted for signs of thyroid disease in the seaside region of Sibenik, Croatia. In this region, salt is regularly iodised with $0.01 \%$ potassium iodide. Thyromegaly was found in 152 children $(2 \cdot 8 \%)$. The most common disorder was simple goitre, which was established in 126 of these, 12 boys and 114 girls (combined prevalence of $2 \cdot 3 \%$, and of $0 \cdot 45 \%$ in boys and $4 \cdot 07 \%$ in girls). Juvenile autoimmune thyroiditis was found in 19 of the children (prevalence $0 \cdot 35 \%$ ), with a female:male sex ratio of 8:1. Diagnosis was confirmed in all cases by fine needle biopsy. Thyroglobulin antibodies were detected in all 19 of the patients with juvenile autoimmune thyroiditis, but microsomal antibodies in only eight. Three patients had decreased concentrations of thyroxine and raised concentrations of thyroid stimulating hormone (TSH), one of these also with clinical hypothyroidism. Raised concentrations of TSH but with normal triiodothyronine and thyroxine were seen in two patients. Graves' disease was diagnosed in four children, three girls and one boy (combined $0 \cdot 07 \%$ ). Thyroid nodules were identified in three children $(0.055 \%$; two benign adenomas and one cyst). Only seven of the 152 patients with thyromegaly (three with hyperthyroidism and four with simple goitre) had previously sought medical advice, which points to the need for careful thyroid examination of apparently healthy children even in regions where the regular iodide intake is assumed to be sufficient.

(Arch Dis Child 1994; 70: 103-106)
\end{abstract}

Thyromegaly is still a common clinical sign in childhood and adolescence despite the widespread practice of iodising table salt, which has eliminated dietary lack, the most common cause of thyromegaly worldwide, as a factor in many areas. Goitre may occur as a result of stimulation, infiltration, or inflammation of the thyroid and it may be diffuse or nodular, symmetric, or asymmetric. Rare prospective studies in children have shown that enlargement of the thyroid gland may occur in up to $6 \%$ of school aged children. ${ }^{12}$

This study concerns the prevalence and nature of diffuse and nodular goitres found during a survey of 5462 schoolchildren in Šibenik, Croatia, a seaside region where regularly available table salt is iodised $(0.01 \%$ potassium iodide). Mean (SD) daily urinary excretion of iodide in the Šibenik region is $\mathbf{2 9 5}$ (282) $\mu \mathrm{g} / \mathrm{g}$ creatinine. ${ }^{3}$

\section{Subjects and methods}

SUBJECTS

Screening examinations for goitre were carried out in 5462 schoolchildren 11 to 18 years of age (mean $14.4(2 \cdot 2)$ years. There were 2801 girls $(51 \cdot 3 \%)$ and 2661 boys (48.7\%). In all goitrous children, the concentrations of thyroid stimulating hormone (TSH), thyroxine, and triiodothyronine, and the titre of thyroid antibodies were determined. In those with an increased titre of thyroid antibodies, ultrasound examination and fine needle biopsy were performed. In children with nodular goitre, a thyroid scan was also performed.

The controls were selected from the population of 480 children attending one of the schools in the town of Sibenik. A random sample of 160 children was obtained. Ten were excluded either because of positive family history for thyroid disease and/or goitre, or the presence of an intercurrent acute or chronic disease. The rest of 150 children (78 girls and 72 boys) aged $10-18$ years (mean $14 \cdot 2(2 \cdot 1)$ years) provided the control group. None had an increased titre of thyroid antibodies. The following values (mean (2SD) (range)) were found for thyroid hormones and TSH: triiodothyronine $=2 \cdot 16 \quad(0.48) \mathrm{nmol} / 1 \quad(1 \cdot 2-3 \cdot 1$ $\mathrm{nmol} / \mathrm{l})$; thyroxine $=102.56(18.53) \mathrm{nmol} / \mathrm{l}$ $(70.5-144.6 \mathrm{nmol} / 1) ; \mathrm{TSH}=1.54(0.71) \mathrm{mU} / \mathrm{l}$ $(0 \cdot 11-2.97 \mathrm{mU} / \mathrm{l})$. These values were considered normal for thyroid function tests and used for comparison with the children screened.

\section{METHODS}

Concentrations of triiodothyronine, thyroxine, and TSH were determined by radioimmunoassay using the kits of INEP (Yugoslavia). Intra-assay coefficients of variation for these were $2 \cdot 7,3 \cdot 0$, and $7 \cdot 8 \%$ respectively, and interassay coefficients of variation were $3 \cdot 1$, $3 \cdot 0$, and $6 \cdot 4 \%$. Thyroid microsomal antibodies were identified by haemagglutination using the kit Serodia AMC (Fujirebio Inc, Japan) (positive $1: 100$ or greater) and by radioimmunoassay using the kits of Biodata (Italy) (positive $17 \mathrm{kU} / 1$ or greater). Thyroglobulin antibodies were assayed by radioimmunoassay using kits from INEP (positive 1:500 or greater).

The same examiner was responsible for screening all of the 5462 children, and the following classification of thyroid hyperplasia was used: grade 0 - not palpable; grade I - 
Table 1 Occurrence of goitre in children by age

\begin{tabular}{lcc}
\hline Age (years) & No of children & No (\%) with goitre \\
\hline $10-10.9$ & 721 & $6(0 \cdot 8)$ \\
$11-11 \cdot 9$ & 672 & $2(0 \cdot 3)$ \\
$12-12 \cdot 9$ & 703 & $10(1 \cdot 4)$ \\
$13-13.9$ & 658 & $16(2 \cdot 4)$ \\
$14-14.9$ & 788 & $34(4 \cdot 3)$ \\
$15-15.9$ & 745 & $29(3 \cdot 9)$ \\
$16-16.9$ & 659 & $27(4 \cdot 1)$ \\
$17-17 \cdot 9$ & 516 & $28(5 \cdot 4)$ \\
Total & 5462 & $152(2 \cdot 8)$ \\
\hline
\end{tabular}

palpable, visible only with head raised; grade II easily visible with head in normal position; grade III - visible at a distance. ${ }^{4}$ All children reported to have some thyroid abnormality were referred for further examinations and definitive classification by two additional physicians. Ultrasound imaging was performed with ultrasound camera Aloka SSD-256, and thyroid scan was performed using technetium-99m. Biopsy of the thyroid was obtained by percutaneous fine needle aspiration. Bone age determinations followed the standards of Greulich and Pyle.

The study was approved by the regional ethical committee for medical research and informed consent was obtained from all children/parents with thyromegaly and the controls.

\section{Results}

Among the 5462 children examined, goitre was detected in $152(2 \cdot 8 \%)$. Divided by sex, 137 out of 2801 girls were goitrous (4.9\%) and 15 out of the 2661 boys $(0.6 \%)$ were goitrous, giving a female:male ratio of $8: 1$. The

Table 2 Occurrence of thyroid diseases in 5462 schoolchildren

\begin{tabular}{llllllll}
\hline & \multicolumn{2}{l}{ No of subjects } & & \multicolumn{2}{l}{ Rates $/ 100$} & \\
\cline { 2 - 7 } Disease & $\begin{array}{l}\text { Boys } \\
(n=2661)\end{array}$ & $\begin{array}{l}\text { Girls } \\
(n=2801)\end{array}$ & Both & & Boys & Girls & Both \\
\hline Simple goitre & 12 & 114 & 126 & 0.45 & 4.07 & 2.30 \\
JAT & 2 & 17 & 19 & 0.07 & 0.61 & 0.35 \\
Graves' disease & 1 & 3 & 4 & 0.04 & 0.11 & 0.07 \\
Benign adenoma & 0 & 2 & 2 & 0.00 & 0.07 & 0.04 \\
Cyst & 0 & 1 & 1 & 0.00 & 0.03 & 0.02 \\
Total & 15 & 137 & 152 & 0.56 & 4.89 & 2.78 \\
\hline
\end{tabular}

prevalence of thyromegaly showed a steady increase with age (table 1). Thyroid enlargement was classified as mild (grade I) in 124 $(81 \cdot 6 \%)$, moderate (grade II) in $27(17 \cdot 7 \%)$, and severe (grade III) in only one $(0 \cdot 7 \%)$.

On the basis of clinical and laboratory findings for these 152 children, simple goitre was diagnosed in $126(82.9 \%)$ and juvenile autoimmune thyroiditis (JAT) in $19(12.5)$. Four $(2 \cdot 6 \%)$ had Graves' disease, and solitary nodules were identified in three, consisting of two adenomas and one cyst (2\%) (table 2$)$.

\section{SIMPLE GOITRE}

The overall prevalence of simple goitre was $2 \cdot 3 \%$. All of the 126 children showed diffuse enlargement of the thyroid, all were asymptomatic (euthyroid) and with negative personal history for iodine deficiency or goitrogen ingestion. The female:male ratio was $9 \cdot 5: 1$ (114 girls and 12 boys). Mean thyroxine $(93.39(14.45) \mathrm{nmol} / \mathrm{l})$ was significantly lower $(\mathrm{p}<0.01)$ and mean TSH $(1.84(0.68) \mathrm{mU} / \mathrm{l})$ was significantly higher $(p<0.01)$ than in the control group, whereas the mean triiodothyronine $(2 \cdot 04(0 \cdot 43) \mathrm{nmol} / \mathrm{l})$ showed no statistical difference.

JUVENILE AUTOIMMUNE THYROIDITIS

The prevalence of JAT in the whole population of children examined was $0.35 \%$ with a female:male ratio of $8 \cdot 1$. Thus JAT was diagnosed in the same proportion of goitrous children by sex, that is 17 out of 137 girls $(12.4 \%)$ and two out of 15 boys (13.3\%). The prevalence of the disease increased with age (table 3 ). The clinical and laboratory data in 19 patients with JAT are shown in table 3 . The goitrous enlargement was grade I (mild) in 12 and grade II (moderate) in seven. The thyroid displayed increased firmness in 15 patients, and was of normal consistency in four patients; the surface was described as pebbly or bosselated in 12, and as smooth in seven patients. Only one patient (number 12) had feeling of pressure and tenderness in the neck.

Table 3 Results of thyroid studies in 19 children with $¥ A T$

\begin{tabular}{|c|c|c|c|c|c|c|c|c|c|c|c|}
\hline \multirow[b]{2}{*}{$\begin{array}{l}\text { Patient } \\
\text { No }\end{array}$} & \multirow[b]{2}{*}{$\begin{array}{l}\text { Age } \\
\text { (years) }\end{array}$} & \multirow[b]{2}{*}{ Sex } & \multicolumn{3}{|l|}{ Goitre } & \multirow[b]{2}{*}{$\begin{array}{l}T S H \\
(m U /)\end{array}$} & \multirow[b]{2}{*}{$\begin{array}{l}\text { Thyroxine } \\
\text { (nmoll) }\end{array}$} & \multirow[b]{2}{*}{$\begin{array}{l}\text { Triiodothyronine } \\
\text { (nmoll) }\end{array}$} & \multirow[b]{2}{*}{$\begin{array}{l}\text { Thyroglobulin } \\
\text { antibodies }^{\star}\end{array}$} & \multicolumn{2}{|c|}{ Thyroid microsomal antibodies } \\
\hline & & & Grade & Consistency & Surface & & & & & $\begin{array}{l}\text { Haemagglutination } \\
\text { titre }\end{array}$ & $\begin{array}{l}k U \cap \text { by } \\
\text { radioimmunoassay }\end{array}$ \\
\hline 1 & 18 & $\mathrm{~F}$ & I & Firm & Pebbly & 1.6 & $78 \cdot 0$ & 1.5 & $1: 7400$ & $1: 0$ & $<17$ \\
\hline 2 & 18 & $\mathrm{~F}$ & II & Firm & Pebbly & 0.56 & $76 \cdot 0$ & 1.75 & 1:7500 & $1: 102400$ & 224 \\
\hline 3 & 11 & $\mathrm{~F}$ & II & Firm & Pebbly & $9 \cdot 2$ & 121.0 & $2 \cdot 0$ & 1:7900 & $1: 25600$ & 144 \\
\hline 4 & 15 & $\mathrm{~F}$ & I & Firm & Pebbly & $1 . \overline{6}$ & $78 \cdot 0$ & 1.35 & $1: 1400$ & $1: 0$ & $<17$ \\
\hline 5 & 14.5 & $\mathrm{~F}$ & I & Normal & Smooth & $2 \cdot 6$ & $78 \cdot 0$ & $2 \cdot 4$ & $1: 5300$ & $1: 0$ & $<17$ \\
\hline 6 & 16 & $\mathrm{~F}$ & II & Firm & Pebbly & $2 \cdot 9$ & $92 \cdot 0$ & 1.8 & $1: 7150$ & $1: 0$ & $<17$ \\
\hline 7 & 15 & $\mathrm{~F}$ & I & Firm & Smooth & $4 \cdot 0$ & $98 \cdot 0$ & $1 \cdot 05$ & $1: 5900$ & $1: 0$ & $<17$ \\
\hline 8 & $15 \cdot 5$ & $\mathbf{F}$ & I & Normal & Smooth & $3 \cdot 1$ & $76 \cdot 0$ & 1.8 & $1: 21250$ & $1: 400$ & 34 \\
\hline$\stackrel{\circ}{9}$ & 16 & $\mathbf{F}$ & I & Firm & Smooth & $1 \cdot 7$ & $80 \cdot 0$ & 1.9 & $1: 14350$ & $1: 0$ & $<17$ \\
\hline 10 & 17 & $\mathrm{~F}$ & II & Firm & Pebbly & $3 \cdot 2$ & $64 \cdot 0$ & 1.4 & $1: 13200$ & $1: 25600$ & 248 \\
\hline 11 & 13 & $\mathrm{~F}$ & I & Firm & Pebbly & 1.6 & $74 \cdot 0$ & $2 \cdot 7$ & $1: 1450$ & $1: 0$ & $<17$ \\
\hline 12 & 11.5 & $\mathbf{M}$ & II & Firm & Pebbly & $5 \cdot 0$ & $59.0 \bigvee$ & $2 \cdot 4$ & $1: 9160$ & $1: 25600$ & 142 \\
\hline 13 & 17 & $\mathrm{~F}$ & I & Firm & Smooth & 2.5 & $92 \cdot 0$ & 2.35 & $1: 2100$ & $1: 0$ & $<17$ \\
\hline 14 & 14 & F & II & Firm & Pebbly & $80 \cdot 0$ & $40 \cdot 0$ & $2 \cdot 5$ & $1: 50000$ & $1: 6400$ & 86 \\
\hline 15 & 13.5 & $\mathbf{M}$ & I & Firm & Pebbly & $1 \cdot 1$ & $76 \cdot 0$ & $2 \cdot 65$ & $1: 6250$ & $1: 0$ & $<17$ \\
\hline 16 & 18 & $F$ & II & Firm & Pebbly & $2 \cdot 0$ & $74 \cdot 0$ & 1.95 & $1: 5300$ & $1: 0$ & $<17$ \\
\hline 17 & 14 & $\mathrm{~F}$ & II & Firm & Pebbly & 0.9 & $114 \cdot 0$ & $2 \cdot 1$ & $1: 6100$ & $1: 25600$ & 72 \\
\hline 18 & 18 & $\mathrm{~F}$ & I & Normal & Smooth & $1 \cdot 3$ & 98.0 & 1.8 & $1: 7500$ & $1: 0$ & $<17$ \\
\hline 19 & $17 \cdot 5$ & $\mathrm{~F}$ & I & Normal & Smooth & $2 \cdot 1$ & $100 \cdot 0$ & $2 \cdot 4$ & $1: 14350$ & $1: 400$ & 86 \\
\hline Normal & & & & & & $0 \cdot 1-3 \cdot 0$ & $70 \cdot 5-140$ & $1 \cdot 2-3 \cdot 1$ & $<1: 500$ & $<1: 100$ & $<17$ \\
\hline
\end{tabular}


In 14 out of 19 patients the concentrations of triiodothyronine, thyroxine, and $\mathrm{TSH}$ were within reference values. Three patients (numbers 10,12, and 14) had lower concentrations of thyroxine and raised concentrations of TSH, and patient number 14 had clinical signs of hypothyroidism. Raised concentrations of TSH with normal triiodothyronine and thyroxine in patients number 3 and 7 pointed to subclinical hypothyroidism. The thyroglobulin antibody titre was raised in all patients. Because thyroid microsomal antibodies were demonstrated by haemagglutination in only eight patients, they were measured repeatedly by radioimmunoassay in all 19 patients, but were again ascertained in the same eight patients. Echographic appearance of the thyroid (diffuse hypoechogenicity) and fine needle biopsy (lymphocytic infiltration) confirmed the diagnosis of JAT in all of the patients.

All patients had normal growth velocity and the height was in all cases at the 25-90th centile. In all five hypothyroid patients (numbers 3, 7, 10, 12, and 14), bone age corresponded to their chronological age.

\section{GRAVES' DISEASE}

Graves' disease was diagnosed in four out of the total 5462 children examined (giving an overall prevalence of $0.073 \%$ ). In three of these patients, two girls, aged 12 and 18 years, and one boy aged 17 years, the diagnosis had been established earlier (in the girls at the age of 11 years and in the boy at 12 years). All three had been on methimazole and were euthyroid at the time of the study. The fourth (a girl) was diagnosed during the study and was started on treatment with methimazole. Exophthalmos was present only in the boy.

\section{BENIGN NODULAR LESIONS}

Overall prevalence of benign nodular lesions was $0.055 \%$ (three out of 5462 examined children). All three of these children had normal concentrations of thyroid hormones and TSH, and thyroid antibodies were absent. Two girls, aged 13 and 14 years, had solitary cold nodules, which were proved by fine needle biopsy to be adenomatous. Both of these children took L-thyroxine, but without significant effect three months after starting treatment. The third child, a girl aged 16 years, has a cyst which has reduced in size after fine needle biopsy.

\section{Discussion}

Simple goitre, described also in the literature as colloid, non-specific, or idiopathic goitre, occurs with a range of prevalencies ( 1 to $6 \%$ ) in different populations of children and adolescents. ${ }^{1256}$ The prevalence of simple goitre of $2.8 \%$, the increasing prevalence with age, and the female to male ratio of $8: 1$ in our survey, correspond to the results from other similar studies carried out in the regions with normal iodine intake in food. ${ }^{267} \mathrm{As}$ in our examined population we found no evidence of iodine deficiency (salt is iodised and urinary excretion of iodine is normal) and no evidence of goitrogen ingestion or iodine excess in food we propose dyshormonogenesis as a result of heterozygosity, the presence of thyroid growth stimulating antibodies, ${ }^{89}$ or simple incapacity of the thyroid to respond to increased metabolic needs in puberty.

In the past 20 years JAT has been more extensively described, probably due to advanced diagnostic methods, although a true increase in its frequency is quite possible. In any case, it is one of the most frequent thyroid diseases in childhood. A study among American schoolchildren showed a JAT prevalence of $1.2 \%,{ }^{10} 1 \%$ is found in Finland and Sweden, ${ }^{11} 120 \cdot 3 \%$ and $0 \cdot 17 \%$ is reported in Japan. ${ }^{1314}$ According to Hung et al out of 77 American children with euthyroid goitre, 43 had JAT. ${ }^{15}$ Ling et al found as many as 43 children with JAT among 66 patients with non-toxic goitre. ${ }^{16}$

We have found $0.35 \%$ prevalence of JAT in our population of schoolchildren, and $12.5 \%$ prevalence among children with goitre. The true prevalence is probably even higher because: (a) at the very beginning of the disease not all patients have blood thyroid antibodies and (b) possibly there are patients with atrophic autoimmune thyroiditis without goitre, an otherwise rare form of JAT in children, which could not be identified in our study for lack of further examinations. The increased prevalence of JAT with age, and the girl to boy ratio of $8: 1$ in our study correspond with the results of other investigations, ${ }^{11} 15$ although it is recognised that the study of Rallison et al identified a ratio of only $2: 1.1^{10}$ Results of our investigation regarding the size of the thyroid (I and II stage), consistency (mostly hard), and surface (pebbly or smooth), correspond to those found in other studies. ${ }^{10} 1117$

Regarding the kinds of thyroid antibodies and their titres in JAT, published results differ. According to Scherbaum ${ }^{18}$ and Amino et al, ${ }^{19}$ thyroid microsomal antibodies are more prevalent than thyroglobulin antibodies, but Ivarrson et $a l,{ }^{20}$ Burek et $a l,{ }^{21}$ and Maagoe et $\mathrm{al}^{22}$ have all shown that raised thyroglobulin antibodies alone are a more specific indication for JAT. In general, all authors agree that titres of thyroid antibodies are higher in adults than in children, in whom they can even be absent. ${ }^{1023}$ The absence of thyroid antibodies, according to Belfiore and Bottazzo, should be considered as false negative in patients in whom JAT has been confirmed by other tests such as fine needle biopsy. ${ }^{24}$ All of our 19 patients with JAT had high thyroglobulin antibody titres (measured by radioimmunoassay, but thyroid microsomal antibodies (measured by haemagglutination and radioimmunoassay) were detected only in eight (that is $42 \%$ ). It may be concluded that positive titres of thyroglobulin antibodies, even when thyroid microsomal antibodies are absent, could be reliable in the diagnosis of JAT.

JAT is one of the most frequent causes of acquired hypothyroidism in children. ${ }^{18}{ }^{19}$ Four of 32 patients in the study of Greenberg et al ${ }^{17}$ 
and nine of 22 patients in the Mäenpää study ${ }^{11}$ were hypothyroid. Fisher et al found a prevalence of $\mathbf{1 8 . 4 \%}$ for hypothyroidism in all patients with JAT. ${ }^{25}$ In the present study of 19 patients with JAT, one had clinical and chemical (overt), two had chemical, and two had subclinical hypothyroidism. None had hyperthyroidism. All of these hypothyroid JAT patients had normal growth rates and bone age. This could be because thyroid insufficiency was not of long duration. Treatment with L-thyroxine resulted within three months in normalisation of plasma concentrations of $\mathrm{TSH}$, triiodothyronine, and thyroxine in all five, and a decrease of goitre size in three of them.

Graves' disease is relatively uncommon in children. Only $1 \%$ to $5 \%$ of all patients with Graves' disease are younger than 16 years. ${ }^{26}$ The large study of Rallison et al is one of the few, if not the only, to address the frequency of childhood thyrotoxicosis. ${ }^{7}$ In that study of 5179 schoolchildren, the prevalence was $0.13 \%$, almost double the prevalence in our study on a similar number of children. The female to male ratio in the study of Rallison et al was $4: 3$ compared with our ratio of $3: 1$, while other authors mention ratios of 4-6:1.26 27

Although thyroid nodules are unusual in childhood and adolescence, they demand careful consideration because of the likelihood that they represent malignancy. Rallison et al found 26 benign nodular lesions and two malignant neoplasms in 5179 schoolchildren tested. ${ }^{28}$ Looking at an only slightly greater number of schoolchildren, we found benign adenomas numbering only two, and a single instance of a thyroid cyst. One possible explanation for such a marked difference in occurrence of these thyroid alterations in these two groups could be the fact that a considerable number of the American children were exposed to radiation fallout. This is supported by results of the study conducted on the general population in Tecumseh, Michigan, among whom only $0.8 \%$ of nodular goitres were found and none of these in any patient under 19 years. $^{2}$

It is important to stress that thyroid disease in our patients was diagnosed before the time of the study in only a small number of children (three with Graves' disease, and four with simple goitre). Because $2 \cdot 8 \%$ of examined children had thyroid abnormalities and some even needed treatment, it is necessary to conduct a thorough examination of the thyroid even in apparently healthy children in regions where regular iodine intake is established.

We are grateful to Christopher Crawford and Katica Ivković for their expert assistance in preparing the manuscript.

Presented in part at 3rd Joint Meeting of The European Society of Pediatric Endocrinology and Lawson Wilkins 1989, Jerusalem.
1 Trowbridge FL, Matovinović J, McLaren GD, Nichaman MZ. Iodine and goiter in children. Pediatrics 1975; 56: 82-90.

2 Matovinović J, Hayner NS, Epstein FH, Kjelsberg MO. Goiter and other thyroid disease in Tecumseh, Michigan. fAMA 1965; 192: 134-40.

3 Tonkić $\mathrm{A}$, Banovac $\mathrm{K}$, Tišlarić $\mathrm{D}$, Sekso $\mathrm{M}$. Concentration of triiodothyronine and thyroxine in two geographically of triiodothyronine and thyroxine in two geographically separate

4 Stanbury JB, Ermans AM, Hetzel BS, Querido A. The public health significance and prevention in endemic goiter and cretinism. World Health Organisation Chronicle 1974; 28: 220.

5 Peden VH, Monteleone JA, Horvath VF. Incidence of goiter in elementary school population. $\mathcal{F}$ Pediatr 1975; 86: 816-7.

Murray TK: Prevalence of goiter in Canada (letter). $A m \mathcal{F}$ Clin Nutr 1977; 30: 1573-4.

7 Rallison ML, Dobyns BM, Keating FR, Raill JE, Tyler FH. Thyroid disease in children. A survey of subjects potentially exposed to fallout radiation. Am $\mathcal{F}$ Med 1974; 56: tially expos

8 Smyth A, Neyland D, O'Donovan DK. Association of thyroid-stimulating immunoglobulins and thyrotropinreleasing hormone responsiveness in women with euthyroid goiter. F Clin Endocrinol Metab 1981; 57: 1001-6.

9 Drexhage HA, Bottazzo GH, Doniach D, Bitonsky L, Chayon J. Evidence for thyroid growth stimulating immunoglobulin in some goitrous thyroid diseases. Lancet 1980; ii: 287-91.

10 Rallison L, Dobyns BM, Keating FR, Rall JE, Tyler FH. Occurrence and natural history of chronic lymphocytic Occurrence and natural history of chronic lymphocy

thyroiditis in childhood. $\mathcal{f}$ Pediatr $1975 ; 86: 675-82$.
11 Mäenpăă J. Juvenile goitrous autoimmune thyroditis. Acta Paediatr Scand 1972; 61: 49-62.

12 Saxena KM, Crawford JD. Juvenile thyroiditis. Pediatrics 1962; 30: 917-21.

13 Niimi H, Sasaki N, Matsumoto S, Kadomura T, Nakamura $Y$. Epidemiological study on the incidence of chronic lymphocytic thyroditis in childhood. Folia Endocrinologica faponica 1976; 52: 1040-5.

14 Inoru M, Taketani N, Sato T, Nakajima H. High incidence of chronic lymphocytic thyroditis in apparently healthy schol chical study. Endocrinol fpn 1975; 22: 483-7.

15 Hung N, Chandra R, August GP, Altman PR. Clinical, laboratory and histologic observations in euthyroid child and adolescent with goiter. $\mathcal{f}$ Pediatr 1973; 82: child 6 .

16 Ling SM, Kaplan SA, Weitzmann J, Reed GB, Costin G, Landing BH. Needle biopsy with other clinical and laboratory findings in chronic lymphocytic thyroiditis and simple goiter. Pediatrics 1964; 44: 695-708.

17 Greenberg AH, Czernichow P, Hung W, Shelley W, Winship T, Blizzard RM. Juvenile chronic lymphocytic thyroiditis: clinical, laboratory and histological correlations. Fournal of Clinical Endocrinology 1970; 30: 293-301.

18 Scherbaum WA. On the clinical importance of thyroid microsomal and thyroglobulin antibody determination. Acta Endocrinol (Copenh) 1987; suppl 281: 325-9.

19 Amino N, Hagan SR, Yamada N, Refetoff S. Measurement of circulating thyroid microsomal antibodies by the of circulating thyroid microsomal antibodies by the tanned red cell haemagglutination technique: its useful-
ness in the diagnosis of autoimmune thyroid diseases. Clin ness in the diagnosis of autoimmun

20 Ivarsson SA, Ericsson UB, Frederiksson B, Persson $H$. Ultrasonic imaging in the differential diagnosis of diffuse thyroid disorders in children. Am $\mathcal{f}$ Dis Child 1989; 143: 1369-72.

21 Burek CL, Hoffman WH, Rose NR. The presence of thyroid autoantibodies in children and adolescents with autoimmune thyroid disease and in their siblings and parents. Clin Immunol Immunopathol 1982; 25: and parents

22 Maagoe H, Reintoft I, Christensen HE, Simonsen J, Mogensen EF. Lymphocytic thyroiditis: I. correlation Mogensen EF. Lymphocytic thyroiditis: I. correlation between morphological, immunological and clinical

23 Volpe R. Etiology, pathogenesis, and clinical aspects of thyroiditis. Pathol Annu 1978; 13: 399-413.

24 Belfior EA, Bottazzo GF. Epidemiology of autoallergic human thyroiditis. Monogr Allergy 1987; 21: 215-45.

25 Fisher DA, Oddie TH, Johnson DE, Nelson JC. The diag nosis of Hashimoto's thyroiditis. $\mathcal{F}$ Clin Endocrinol Metab 1975; 40: 795-801.

26 Saxena KM, Crawford JD, Talbolt B. Childhood thyrotoxicosis: a long term perspective. $B M F$ 1964; ii: $1153-8$. Măenpäă J, Kuusi A. Children with hyperthyroidism. Acto Paediatr Scand 1980; 69: 137-42.

28 Rallison ML, Dobyns BM, Keating FR, Rall JE, Tyler FH. Thyroid nodularity in children. $\mathscr{f} A M A$ 1975; 233: 1069-72. 